\section{NEWTONOVA METODOLOGIE A KRITIKA MECHANICKÉHO MATERIALISMU}

\begin{abstract}
Abstrakt: $V$ tomto článku budou představeny základní aspekty metodologie Isaaca Newtona aplikované $v$ Principia Mathematica na řešení otázky povahy gravitační síly. Metoda vyvozování propozic př́rodních jevů může být označena jako demonstrativní indukce. Cílem článku je ukázat, že tato metoda, jak ji zastával Newton, $v$ sobě explicitně obsahovala kritiku hypoteticko-deduktivní metody jako zcela neadekvátního prístupu ke zkoumání prírody. Oproti hypoteticko-deduktivní metodě je demonstrativní indukce schopna produkovat teorie empiricky i epistemologicky mnohem bohatší. Vymezení se vi̊či hypoteticky založeným teoriím je úzce spjato s kritikou mechanického materialismu především v podobě, v jaké ji zastával René Descartes. Ve svých di̊sledcích to Newtona dovedlo nejen $k$ odmitnutí univerzálnosti mechanické premisy, ale také $k$ určité imunizaci vi̊či veškerým konkurenčním hypoteticky založeným teoriím.
\end{abstract}

Klíčová slova: Newton; metodologie; mechanický materialismus; indukce; hypotéza

\section{ROMAN ZAVADIL}

Katedra filosofie, Filozofická fakulta Univerzita Palackého v Olomouci Kř́žkovského 12, 77900 Olomouc email / roman.z@seznam.cz

\section{Newton's Methodology and Criticism of Mechanical Materialism}

Abstract: This article will introduce Isaac Newton's fundamental methodological concepts applied for a solution concerning a question of gravity in his Principia Mathematica. The method of deduction of propositions from phenomena can be described as demonstrative induction. The main aim is to show that this method proposed by Newton explicitly contains a criticism of hypotheticodeductive methodology as an inadequate approach to the study of nature. As opposed to hypothetico-deductive method, demonstrative induction is capable of producing theories with much richer empirical and epistemological value. Delimitation against hypothetically deduced theories is closely connected with criticism of mechanical materialism, most notably in a form proposed by René Descartes. Consequently, it has led Newton to not only reject the universality of mechanical premise but also to certain level of immunization against all competitive hypothetically based theories.

Keywords: Newton; methodology; mechanical materialism; induction; hypothesis
(iD) 0000-0003-3249-6146

Příspěvek vznikl za podpory MŠMT ČR, udělené UP v Olomouci IGA_FF_2020_003).

(c) Toto dílo podléhá licenci Creative Commons Attribution 4.0 International. 
Vědecká revoluce 16. a 17. století představovala bezprecedentní a turbulentní období zásadních změn ve všech oblastech přírodní filosofie. Ta v sobě obsahovala $v$ současnosti již separátní vědecké disciplíny jako astronomii, mechaniku, optiku, medicínu apod. ${ }^{1}$ Nepochybně nejvýznamnější proměnou prošla astronomie a fyzika. Vydání Koperníkových děl Commentariolus ${ }^{2}$ (1514) a De revolutionibus orbium coelestium (1543) zahájilo přerod centrálního kosmologického paradigmatu ptolemaiovského modelu. Předložená heliocentrická teorie byla užitečná především jako kvalitativní či semikvalitativní analýza oběžných drah planet, nicméně oproti ptolemaiovskému modelu měla mnoho praktických a estetických výhod ${ }^{3}$ např. jednodušší vysvětlení retrográdního pohybu planet. ${ }^{4}$ Namísto zavádění složitých modelů epicyklu, deferentu a ekvantu jednotlivých planet tak mohl Koperník tento pohyb vysvětlit pomocí orbitálního pohybu Země kolem Slunce. ${ }^{5}$

Kvantitativního základu se heliocentrickému modelu dostalo až počátkem 17. století z pera Johannese Keplera v dílech Astronomia Nova (1609) a Harmonices Mundi (1619), kde formuloval tři zákony o oběžných drahách těles. Významným př́nosem zákonů jsou také jejich kosmologické implikace. Podle prvního zákona jsou orbity planet eliptického tvaru. Kepler tak odmítá axiom jednoduchých i složených ${ }^{6}$ kruhových orbit planet platný ve všech dosavadních kosmologiích. ${ }^{7}$ Druhý zákon neguje další z př̀edpokladů starších modelů, a to uniformitu rychlosti pohybu planet. Problém s kolísáním rychlosti pohybu planet se řešil v ptolemaiovském modelu zavedením ekvantu. Kepler matematicky popsal vztah mezi parametry rychlosti a času. Třetí zákon publikoval až s desetiletým zpožděním ve druhém výše

\footnotetext{
${ }^{1}$ John Henry, The Scientific Revolution and the Origins of Modern Science (New York: Palgrave, 2002), 4.

${ }^{2}$ Celým názvem Nicolai Copernici de hypothesibus motuum coelestium a se constitutis commentariolus.

3 James T. Cushing, Philosophical Concepts in Physics: The Historical Relation Between Philosophy and Scientific Theories (Cambridge: Cambridge University Press, 1998), 62.

${ }^{4}$ Retrográdní pohyb popisuje pohyb planet, jež se pohybují relativně $\mathrm{k}$ fixním hvězdám. Zatímco většinu času se, narozdíl od Slunce a Měsíce, pohybují ze západu na východ, jejich zdánlivý směr pohybu se periodicky mění z východu na západ. Viz K. Lee Lerner and Brenda Wilmoth Lerner, Scientific Thought: In Context (Gale: Cengage Learning, 2009), 33.

${ }^{5}$ Viz Nicolaus Copernicus, "Commentariolus," in Three Copernican Treatises, ed. Edward Rosen (New York: Octagon Books, 1971), 58-59.

${ }^{6}$ Jednoduchý kruhový pohyb platí pouze pro sféru stálic. Pohyb planet, ač také kruhový je složen z dvou kruhových pohybů, a to kolem středu soustavy (tzv. deferent) a kolem dráhy deferentu (tzv. epicyklus).

${ }^{7}$ Vedle ptolemaiovského a kopernikánského modelu také pojetí Braheho a Galileiho obsahovala předpoklad cyklických orbit.
} 
zmíněném spise. Zde dává do vztahu parametry vzdálenosti a času, přičemž planety jsou integrovány do harmonického systému, $v$ rámci něhož se čas potřebný k uskutečnění jednoho úplného oběhu planety okolo Slunce zvyšuje nepřímo úměrně jejich vzájemné vzdálenosti v konstantním poměru.

Podle Henryho můžeme sledovat metodologickou a epistemologickou transformaci v období vědecké revoluce na rozmachu experimentální filosofie a naopak ústupu spekulativní filosofie. ${ }^{8} \mathrm{Na}$ ty to trendy lze pak pohlížet prizmatem ontologického statutu matematických teorií. Zjednodušeně řečeno se vědecká revoluce snažila nahradit převážně instrumentalistické př́stupy $\mathrm{k}$ matematické analýze realistickým pojetím. Instrumentalisté věřili, že matematicky odvozené teorie jsou předkládány jako hypotetický nástroj pro usnadnění výpočtů a predikcí. Realisté naopak trvali na tom, že matematická analýza odhaluje, jak věci skutečně jsou, jinými slovy, pokud výpočty souhlasí, pak je teorie pravdivá nebo quam proxime pravdivá.

Vyvrcholením astronomických snah bylo vydání hlavního díla Isaaca Newtona Philosophiae Naturalis Principia Mathematica (1687). Newton navazoval na tradici Koperníka, Keplera, Galileiho a mnoha dalších, jejichž myšlenky představovaly významnou část jeho následné práce na Principiích. On sám si byl svého dědictví vědom, když v roce $1676 \mathrm{v}$ dopise Robertu Hookovi napsal: „Pokud jsem viděl dále než ostatní, bylo to proto, že jsem stál na ramenou obrů. "9,10 Je třeba říci, že Newton nenapsal žádné vysloveně metafyzické dílo ve stylu Descarta nebo Leibnize. Přesto jeho práce mají značný filosofický přesah, a to především ve dvou hlavních ohledech. Za prvé, jeho vliv na metodologické aspekty zkoumání přírody a kritika hypoteticko-deduktivní metody (HD), ${ }^{11}$ jako adekvátního nástroje zkoumání prŕrody. Za druhé, Newton povětšinou kriticky reaguje na myšlenky svých předchůdců v oblasti př́rodní filosofie. Pro nás nejzásadnější bude v tomto ohledu jeho kritika mechanického materialismu a kosmologických teorií s ním spojených, zejména teorie vírů Reného Descarta.

Newton nikdy nezastával žádnou souhrnnou metafyzickou pozici jako dualismus, nebo monismus ani nepředložil nějakou obecnou epistemologickou teorii. Ve svém díle se nicméně systematicky zabývá těmi aspekty

\footnotetext{
${ }^{8}$ Henry, Scientific Revolution, 15.

9 „Isaac Newton to Robert Hooke, February 5, 1675/6,“ in The Correspondence of Isaac Newton, Vol. 1, 1661-1675, ed. Herbert W. Turnbull (Cambridge: Cambridge University Press, 1959), 416.

${ }^{10}$ Není-li uvedeno jinak, př̀eklad vlastní. Veškeré citáty z Principií vycházejí ze třetí edice.

${ }^{11}$ Hypoteticko-deduktivní metoda mechanických materialistů je ve mnoha ohledech odlišná od metody logických pozitivistů.
} 
metafyziky, které jsou velice úzce spojeny s jeho matematickou prací ve fyzice. Následkem nucené obrany vưči námitkám především ze strany mechanistických filosofü tak vytvořil inovativní koncepci vztahu mezi fyzikou a metafyzikou. ${ }^{12}$

Než budeme moci přejít ke konkrétní aplikaci Newtonovy metodologie na řešení otázky povahy gravitace, je třeba si vyjasnit několik klíčových teoretických konceptů.

\section{Koncept sil a pohybové zákony}

Definice v úvodu Principií začínají vymezením pojmu „hmotnosti“13 tělesa na základě parametrů hustoty a objemu. ${ }^{14}$ Toto inovativní pojetí nahrazuje neadekvátní pojmy váhy, preferované $\mathrm{v}$ Galileiho experimentech, a rozprostraněnosti, kterou zastával Descartes. Zásadní výhodou hmotnosti oproti váze je, že zůstává v různých podmínkách konstantní. Newton tak reagoval na experimenty Richera a Halleyho a jejich zjištění, že váha se mění v závislosti na zeměpisné śířce.

Toto pojetí bylo značně ovlivněno pneumatickými experimenty Roberta Boyla a jeho teorií hmoty. Boyle si byl vědom, že dané množství vzduchu se může rozpínat nebo stlačovat. $\mathrm{V}$ takovýchto podmínkách se hustota zmenšuje či zvětšuje, nicméně hmotnost plynu je konstantní, jelikož se odvíjí zároveň od objemu a hustoty. Podle Newtona pak hmotnost jakéhokoli tělesa zůstane konstantní i v př́padě, že ji přemístíme $\mathrm{z}$ jednoho místa na Zemi na jiné. Dokonce i kdybychom přenesli těleso na Měsíc nebo Jupiter, tak hmotnost bude stále stejná. ${ }^{15} \mathrm{~S}$ hmotností je spojen také pojem „hybnosti“, ${ }^{16}$ jenž je definován jako součin rychlosti a hmotnosti tělesa. ${ }^{17}$ Na rozdíl od Descarta zavedl Newton hybnost jako vektorovou veličinu.

Druhým centrálním prvkem u Newtona je pojetí síly. Na rozdíl od starších koncepcí, kde hrála hlavní roli mechanická interakce částic, přichází s pojetím mechaniky založené na principu sil. ${ }^{18}$ Jednou $\mathrm{z}$ ústředních je pro

\footnotetext{
${ }^{12}$ Andrew Janiak, Newton as Philosopher (Cambridge: Cambridge University Press, 2008), 9.

${ }^{13}$ Newton užíval termín quantity of matter (quantitas materiae).

${ }^{14}$ Isaac Newton, Mathematical Principles of Natural Philosophy (Berkeley: University of California Press, 1999), 403.

${ }^{15}$ I. Bernard Cohen, „Newton's Concept of Force and Mass, With Notes on the Laws of Motion," in The Cambridge Companion to Newton, eds. Robert Iliffe and George E. Smith (Cambridge: Cambridge University Press, 2016), 59.

${ }^{16}$ Newton používal termín quantity of motion (momentum).

${ }^{17}$ Newton, Mathematical Principles, 404.

${ }^{18}$ Ibid., 404-8.
} 
něj „vtištěná síla“, ${ }^{19}$ představující sílu, jež je na těleso vyvíjena, za účelem změny jeho klidového stavu nebo pohybu rovnoměrně přímočarého. Trvání vis impressa je pouze po dobu, kdy na těleso působí. Ve chvíli, kdy prrestane působit, zachovává si těleso sílu ve formě setrvačnosti. ${ }^{20}$ Setrvačná síla je tendence tělesa setrvávat $\mathrm{v}$ klidu nebo $\mathrm{v}$ pohybu rovnoměrně přímočarém a je př́mo úměrná hmotnosti tělesa. Přestože se pojem setrvačnosti či setrvačné síly vyskytoval již dříve, Newton jej užíval odlišně od tradice. ${ }^{21,22}$

Závěrečné definice popisují vlastnosti a charakter dostředivé síly, která je zásadní pro Newtonovo pojetí gravitace. Dostředivá síla, jako jedna $\mathrm{z}$ forem vis impressa, ${ }^{23}$ je síla, skrze niž jsou tělesa přitahována nebo jakkoli jinak nucena k pohybu okolo středového bodu. Newton rozlišuje tři hlavní projevy dostředivých sil, které můžeme pozorovat $\mathrm{v}$ př́rodě: gravitační síla Země zapříčiňující pohyb těles směrem $\mathrm{k}$ jejímu středu, magnetické pole a síla působící na planety a zapříčiňující zakřivení jejich drah, jež by při absenci působení jakýchkoli sil byly přímočaré. Oproti ostatním typům vis impressa má dostředivá síla nedostatek spočívající ve způsobu jejího zkoumání. V př́ípadě nárazu i tlaku jsme schopni tuto sílu demonstrovat v rámci triviálního experimentu či běžné zkušenosti, např. náraz dvou koulí. Nicméně dostředivá síla je v tomto ohledu odlišná, jelikož její existenci můžeme usuzovat jen z jejích projevů, jako je zakřivení dráhy planet zmíněné výše.

Definitorický vyznám předešlé části se ukazuje v následném výčtu tří pohybových zákonů:

1. Každé těleso setrvává $\mathrm{v}$ klidu nebo pohybu rovnoměrně př́ímočarém, dokud není nuceno svůj stav změnit vlivem vtištěné síly.

${ }^{19} \mathrm{~V}$ článku je upřednostňován vlastní autorův překlad klíčových pojmů před současnou fyzikální terminologií především pro větší konzistenci s ohledem na původní terminologii Principií.

${ }^{20}$ Newton zastával kategorizaci setrvačnosti jako jedné z inherentních fyzikálních sil, přestože z dnešního pohledu newtonovské mechaniky je setrvačnost vlastností těles.

${ }^{21}$ Newton nebyl originálním autorem tohoto termínu. Podle Lexicon Philosophicum (1613) Rudolfa Goclenia, se vis insita, objevuje jako přirozená vlastnost tělesa, v protikladu k vis violenta. $\mathrm{V}$ aristotelské fyzice tento termín označuje přirozený pohyb. Vis insita se také objevuje v díle Phisiologiae Peripateticae Libri Sex (1642) Johanna Magiruse, se kterou se Newton sám setkal při svém pregraduálním studiu v Cambridge. Viz Cohen, „Newton’s Concept of Force and Mass," 60.

${ }^{22}$ Pro komplexnější deskripci vývoje pojetí síly v 17. století viz François De Gandt, Force and Geometry in Newton's Pricnipia (Princeton: Princeton University Press, 2014), 58-139.

${ }^{23}$ Dalšími jsou náraz (percussion) a tlak (pressure). Těmto nicméně nevěnuje ani zdaleka takovou pozornost, jako dostředivé síle, a to $\mathrm{z}$ pochopitelných důvodů. 
2. Změna pohybu tělesa je vždy úměrná vtištěné hybné síle a působí po přímce ve směru vtištěné síly.

3. Každá akce vyvolává opačnou reakci; vzájemné působení dvou těles je vždy stejné a v opačných směrech. ${ }^{24}$

První pohybový zákon vytváří obecný referenční rámec, v němž jsme schopni aplikovat další zákony. Konkrétně v rámci klasické mechaniky se jedná o inerciální vztažnou soustavu, vzhledem k níž se částice, na kterou nepůsobí žádné síly, pohybuje konstantní rychlostí ve směru přímočarém. ${ }^{25}$ Získáváme tak kvalitativní popis síly způsobující změnu klidového stavu nebo rovnoměrně přímočarého pohybu. Podle druhého zákona dochází ke změně pohybu tělesa $\mathrm{v}$ př́ípadě působení externích sil, přičemž těleso změní svůj pohyb ve směru vtištěné síly. $V$ př́padě působení více sil se těleso pohne ve směru výslednice sil. ${ }^{26}$ Třetí zákon popisuje párovou interakci dvou těles, přičemž pokud jedno těleso působí na druhé danou silou $\mathrm{v}$ daném směru, pak druhé těleso působí na první stejnou silou v opačném směru.

Newton do značné míry vycházel koncepčně z Descartových př́rodních zákonů. Významnou inspirací při formulaci pohybových zákonů mu byl také Christiaan Huygens, který v Horologium Oscillatorium (1673) axiomatizoval Galileiho pohybové zákony pro pohyb těles v gravitačním poli Země. Huygensův první zákon ${ }^{27}$ říká, že pokud by nebyla žádná gravitace ${ }^{28}$ ani odpor vzduchu, každé těleso by setrvávalo $\mathrm{v}$ pohybu rovnoměrném přímočarém. Tato formulace je oproti Newtonovy užší a uvažuje pouze systém, kde jediné

\footnotetext{
${ }^{24}$ Newton, Mathematical Principles, 416-17.

${ }^{25}$ Ve skutečnosti není $\mathrm{v}$ newtonovské mechanice možné, aby těleso zůstalo $\mathrm{v}$ absolutním klidu nebo $\mathrm{v}$ pohybu rovnoměrně přímočarém, pokud není nekonečně daleko od ostatních těles. Každé těleso je totiž vystaveno působením přitažlivých sil ostatních těles. Intenzita těchto sil klesá s druhou mocninou vzdáleností. První pohybový zákon tedy není výsledkem pozorování těles v uniformním rovnoměrně přímočarém pohybu, na které nepůsobí žádná síla. Taková podle Newtona ani pozorovat nejdou. Jedná se spíše o návod, jak analyzovat skutečný pohyb těles na základě dvou faktorů. Za prvé, aktuální rychlost po tečně pozorované trajektorie a za druhé, změna pohybu, kterou těleso prochází. První je považováno za stav, v němž těleso přirozeně setrvává, zatímco druhé je založené na působení externí síly. Viz Roberto Torretti, The Philosophy of Physics (Cambridge: Cambridge University Press, 1999), 46.

${ }^{26}$ Přestože se druhý zákon vztahuje k impulzivnímu působení síly (síly působící okamžitě $\mathrm{v}$ nekonečně krátkém čase), tak se samozřejmě vztahuje i na kontinuální působení síly. Nicméně za účelem větší obecnosti se Newton uchýlil k této formulaci.

${ }^{27}$ V Huygensově pojetí jsou všechny pohybové zákony označeny jako hypotézy.

${ }^{28}$ Podle Huygense byla gravitace stále v mezích mechanické interakce částic. Je třeba tedy odlišovat od toho, jak chápal gravitaci Newton.
} 
působící síly jsou gravitace a tření vzduchu. Druhý zákon popisuje pohyb tělesa, na které působí gravitace dle zákonů volného pádu. Přestože Huygens nevyjadřuje druhý pohybový zákon v tak obecné míře, jako Newton v Principiích, $\mathrm{z}$ hlediska struktury jsou oba modely stejné. Nejprve je popsán setrvačný pohyb při absenci působících sil a následně nový pohyb, který je zapř́činěn působením externích sil. V Principiích Newton dodal tezi o Galileově objevení zákonů vrhu. Podle Newtona k tomu Galileo došel na základě úvah obsahově podobných prvnímu a druhému zákonu. Tím by se stal Galileo třetím zdrojem pro formulace těchto zákonů. Nicméně neexistuje žádná evidence, která by podporovala, že Newton Galileiho Dvě nové vědy četl a jeho povědomí o něm muselo být pouze ze sekundárních zdrojů. ${ }^{29}$

\section{Newtonova metodologie v Principiích}

Principia byl poprvé vydána v roce 1687, druhá a třetí edice pak v letech 1713 a 1726, přičemž všechna původní vydání byla psaná v latině. První anglický překlad od Andrew Motteho je z roku 1729. Struktura díla je založena na prístupu charakteristickém především pro díla z oblasti geometrie a tento úzký interdisciplinární vztah je patrný již v předmluvě, kde autor žádá přiblížení se exaktnosti geometrické metody. První část je věnována základním definicím klíčových pojmů jako hmotnost a jednotlivým typům fyzikálních sil a zakončena je popisem třech axiomů, $\mathrm{v}$ tomto př́padě pohybovým zákonům. Zbytek Principií je dělen na tři knihy. První kniha pojednává o volném pohybu těles (pohyb v prostoru bez přítomnosti tření), založeném na koncepci sil z předchozích definic a axiomů. Druhá kniha již pojednává o pohybu těles ve fluidním prostředí (pohyb v prostoru $s$ různou mírou tření) a obsahuje explicitní kritiku karteziánské teorie vírů. Z metodologického hlediska je nejbohatší poslední třetí kniha, kde Newton formuluje tzv. pravidla pro studium př́rodní filosofie (regulae philosophandi), kterážto mají sloužit jako základní metodologický rámec veškerého zkoumání. Zde Newton také aplikuje dosavadní teoretické a metodologické závěry, na jejichž základě popisuje zákon obecné gravitace. $\mathrm{V}$ úplném závěru knihy stojí „Obecné scholium“ sumarizující závěry předešlých knih týkající se pohybu těles a kritiky mechanického materialismu.

$\mathrm{V}$ obecné rovině se Newton na konto metodologických východisek užitých v Principích vyjadřuje velice sporadicky. $V$ úvodu $k 1$. vydání píše, že v knize představí matematické principy př́rodní filosofie, jež budou sloužit

${ }^{29}$ Cohen, „Newton’s Concept of Force and Mass,“ 69-70. 
k odhalení př́rodních sil z pohybu těles, a na základě těchto sil pak vysvětlí další prŕírodní jevy. ${ }^{30}$ První edice pak obsahuje pouze dvě další a velice vágní zmínky. Po jejím vydání se Newton setkal s vlnou metodologických námitek a pod tímto tlakem se rozhodl své metodologické maximy osvětlit. ${ }^{31} \mathrm{~V} 2$. vydání v Obecné scholiu v závěru knihy je jeho postoj jasnější:

Nevytváŕím žádné hypotézy, ${ }^{32}$ protože cokoli není odvozeno z přírodních jevů musí být hypotézou nazýváno a hypotézy, at jsou metafyzické nebo fyzikální, at jsou založeny na okultních kvalitách, nebo mechanických principech, nemají $\mathrm{v}$ experimentální filosofii co pohledávat. $\mathrm{V}$ této filosofii jsou propozice odvozeny z prrírodních jevů a následně pomocí indukce zobecněny. ${ }^{33}$

Již zde je vyjádřeno negativní stanovisko vůči čistě hypoteticky ${ }^{34}$ založeným teoriím mechanického materialismu. V Newtonově metodologii pro hypotézy není místo. Zobecněné teorie jsou založeny na důkladném měření a experimentu dle souboru pečlivě vybraných a ověrených dat. Díky tomu mají propozice získané touto cestou vyšší validitu i reliabilitu. ${ }^{35}$

Podle Dorlinga může být Newtonova metoda označena jako demonstrativní indukce ${ }^{36}$ (DI), kdy jsou univerzální zobecnění odvozena $\mathrm{z}$ jedné nebo více jejích vlastních instancí. Takový typ odvození pak musí obsahovat dodatečné teoretické premisy. Nicméně je důležité, aby žádná z těchto premis explicitně neimplikovala univerzální zobecnění. Taktéž jejich počáteční validita musí být vyšší než validita univerzálního zobecnění, jež z nich

${ }^{30}$ Newton, Mathematical Principles, 382.

${ }^{31}$ George E. Smith, "The Methodology of the Principia," in The Cambridge Companion to Newton, eds. Robert Iliffe and George E. Smith (Cambridge: Cambridge University Press, 2016), 188.

${ }^{32}$ Newtonovo slavné hypotheses non fingo.

${ }^{33}$ Newton, Mathematical Principles, 943.

${ }^{34}$ Newton bohužel nebyl v užití pojmu „hypotéza“ př́liš konzistentní, především v prvním vydání Principií. Nicméně tyto terminologické odlišnosti nebyly natolik významné, aby oslabily jeho kritiku. Viz Norwood R. Hanson „Hypotheses fingo," in The Methodological Heritage of Newton, eds. Robert E. Butts and John W. Davis (Oxford: Blackwell, 1970), 14-33.

${ }^{35}$ První verzi této metodologické maximy Newton vyjádřil v jednom z dopisů Rogeru Cotesovi v roce 1713. Viz „Isaac Newton to Roger Cotes, March 31, 1713, “ in The Correspondence of Isaac Newton, Vol. 5, 1709-1713, eds. A. Rupert Hall and Laura Tilling (Cambridge: Cambridge University Press, 1975), 400.

${ }^{36}$ Demonstrativní indukce je úzce spojena s metodou eliminativní indukce. Viz John D. Norton, „Eliminative Induction as a Method of Discovery: How Einstein Discovered General Relativity," in The Creation of Ideas in Physics, ed. Jarrett Leplin (Dordrecht: Kluwer, 1995), 30. 
chceme odvodit. ${ }^{37}$ Tento univerzální model odvozování z přírodních jevů se stal základem pro většinu následujících úspěšných fyzikálních teorií. Konkrétně tedy máme soubor prírodních jevů, které jsou instancemi jednoho univerzálního zobecnění (obecné gravitace), jehož validita je odvozena z platnosti jednotlivých instancí.

Je zcela očividné, že síla DI metody závisí na přijatelnosti výchozích premis. Výsledné zobecnění často obsahuje nové teoretické entity, kteréžto předtím nebyly ve výchozích předpokladech explicitně přítomné. Newton tak odvodil $\mathrm{z}$ phenomen existenci gravitační síly. ${ }^{38}$ Tato síla $\mathrm{v}$ rámci explanace přesahuje základní rámec pozorování a mủže být považována za př́ičinu pohybu planet. ${ }^{39}$ Teoretický přesah zobecnění nad rámec pozorovaní umožňuje vytváření validních přírodních zákonů, které by jinak byly pouze observačními zákony. DI model tak vytváří z epistemologického hlediska explanace na vyšší úrovni než konkurenční hypoteticko-deduktivní model.

Dalším klíčovým prvkem jsou výše zmíněná pravidla $\mathrm{z}$ úvodu třetí knihy. První dvě byla již v první edici, ${ }^{40}$ třetí bylo přidáno ve druhé a čtvrté pak ve třetím vydání.

Pravidlo 1: Nemělo by být postulováno více příčin, než je nezbytně nutné pro dostatečné vysvětlení přírodních jevů.

Pravidlo $2: \mathrm{Z}$ toho plyne, že prríčiny přiřazené přírodní jevům určitého typu, musí být vždy stejné.

Pravidlo 3: Vlastnosti těles, které nemohu být kvalitativně změněny, tedy nemohou být ani zesíleny ani zeslabeny, a jsou společné všem tě-

${ }^{37}$ Jon Dorling, „Demonstrative Induction: Its Significant Role in the History of Physics,“ Philosophy of Science 40, no. 3 (1973): 360.

${ }^{38}$ Newtonův koncept phenomen je bezpochyby jedním z klíčových prvků jeho př́rodní filosofie. Ve 20. století byla tato koncepce, respektive obecně způsob, jakým byl Newton schopen $\mathrm{z}$ phenomen odvodit zákon obecné gravitace podrobena extenzivní kritice. Jedním $\mathrm{z}$ klíčových děl je $\mathrm{v}$ tomto ohledu Duhemova kniha La Théorie Physique: son Objet et sa Structure. Zde je Newtonovi vytýkáno, že není možné z phenomen (konkrétně z druhého a třetího Keplerova zákona) vyvodit zákon obrácených čtverců, který byl základem pro popis gravitační síly. Viz Pierre Duhem, The Aim and Structure of Physical Theory (Princeton: Princeton University Press, 1991).

${ }^{39}$ Ori Belkind, „Newton's Scientific Method and the Law of Gravitation,“ in Interpreting Newton: Critical Essays, eds. Andrew Janiak and Eric Schliesser (Cambridge: Cambridge University Press, 2012), 143.

${ }^{40} \mathrm{~V}$ první edici byla tato pravidla označena jako hypotézy. 
lesům, jež mohou být předmětem experimentu, by se měly považovat za vlastnosti společné všem tělesům.

Pravidlo 4: V experimentální filosofii by měly být propozice získané z phenomen pomocí indukce považovány za zcela nebo alespoň přibližně pravdivé bez ohledu na protikladné hypotézy, dokud jiná phenomena neučiní tyto propozice bud' přesnější, nebo podléhající výjimkám. ${ }^{41}$

První pravidlo je variací na Ockhamovu břitvu, kdy bychom se měli v našem vysvětlení omezit pouze na entity nezbytně nutné. Druhé rozšiřuje jeho aplikovatelnost. Pokud máme nějaký soubor podobných jevů, např. respirace u člověka a jiných savců, pak kauzální vysvětlení obou jevů budou stejného charakteru. Existuje-li empirické vysvětlení pro jeden př́ípad, není třeba pro další podobné jevy vytvářet nový soubor explanací.

Třetí pravidlo je klíčové pro možnost extrapolace takových parametrů, které jsou z kvalitativního hlediska společné všem předmětům experimentu. Díky tomu jsme schopni provést induktivní zobecnění a získat tak univerzálně platné závěry. Newton explicitně říká, že pouze vlastnosti založené na experimentální verifikaci, můžeme považovat za společné všem tělesům. ${ }^{42}$ Tímto způsobem zabraňuje zavádění obskurních entit, jež nemají žádnou ontologickou podporu v experimentu, do př́rodní filosofie. Zároveň se vymezuje vůči teoriím zavádějícím takové entity a snižuje jejich explanační sílu. Newton nám dává několik př́ikladů takových vlastností:

Rozprostraněnost, tvrdost, neproniknutelnost, ${ }^{43}$ pohyblivost a setrvačnost celku vychází z rozprostraněnosti, tvrdosti, neproniknutelnosti, pohyblivost a setrvačnost jeho jednotlivých částí. A tak můžeme soudit, že každá nejmenší část všech je rozprostraněná, tvrdá, neproniknutelná, pohyblivá a obdařena setrvačnou silou. A toto je základem veškeré prŕírodní filosofie. ${ }^{44}$

Kvalitativní vlastnosti celku jsou souhrnem vlastností jejich jednotlivých částí, jelikož je nemůžeme od těles nijak oddělit, jsou vlastnostmi společnými univerzálně všem tělesům. ${ }^{45}$

\footnotetext{
${ }^{41}$ Newton, Mathematical Principles, 794-96.

${ }^{42}$ Belkind, „Newton's Scientific Method,“ 153

${ }^{43}$ Nemožnost dvou těles nacházet se v témže prostoru.

${ }^{44}$ Newton, Mathematical Principles, 795.

${ }^{45}$ Newton ve 3. pravidle podle Harpera obhajuje specifickou formu atomismu, dle kterého jsou všechny atomy zcela identické a veškeré rozdíly mezi tělesy vyvstávají z odlišných konfigurací atomu v rámci struktury. William L. Harper, Isaac Newton's Scientific Method: Turning Data Into Evidence About Gravity and Cosmology (Oxford: Oxford University Press, 2011), 273.
} 
Pravidlo 4 určuje epistemologický status induktivních inferencí, přičemž ty by měly být brány za pravdivé nebo quam proxime pravdivé. Navíc takto získaná zobecnění jsou imunizována vůči hypotézám. Newton se vymezuje vůči námitkám mechanistických materialistů kritizujících jeho vysvětlení gravitačního působení při absenci vzájemné mechanické interakce částic. Odvolávali se tak na základní premisu mechanického materialismu, tedy požadavek vysvětlení veškerého pohybu a změny $\mathrm{v}$ př́rodě na základě mechanické interakce částic. DI inference však mohou být vyvráceny pouze dalšími induktivně získanými inferencemi. Newton tak předjímá falibilistický předpoklad, jenž je základem současné vědy.

\section{Demonstrativní indukce v praxi: zákon obecné gravitace}

Doposud jsme si ukázali základní teoretický rámec Newtonových Principií, který tkví v kombinaci inovativního př́stupu k pojetí sil a zavedení na nich založených pohybových zákonů. Pravidla př́rodní filosofie pak tvoří hlavní metodologická východiska pro analýzu a syntézu dat získaných z pozorování a experimentu. Dle zásad modelu demonstrativní indukce je třeba nyní ukázat soubor výchozích dat, $\mathrm{z}$ nichž můžeme následně získávat propozice $\mathrm{k}$ deskripci zvoleného systému. Celý tento proces si nyní ukážeme na Newtonově argumentu pro obecnou gravitaci.

Ve 3. knize Newton předkládá šest phenomen ${ }^{46}$ popisující relativní pohyb těles vzhledem ke středu orbity ${ }^{47}$ Nicméně phenomena nejsou pro Newtona pouhá parciální data a jeho užití se do značné míry liší od pojetí „fenomenalistických“ filosofů. Není to vír představ v něčím myšlení, natož soubor smyslových vjemů, ale spíše soubor procesů nebo stavů, který byl skrze podrobnou analýzu jednotlivých pozorování shledán jako skutečná deskripce prŕrody. Všech šest phenomen předložených Newtonem bylo popsáno až po dlouhé a usilovné intelektuální práci. ${ }^{48}$ Newton využívá pozorování a měření svých předchůdců. Mezi phenomena řadí pozorování měsíců Jupitera, Saturnu a Země, ale také předpoklad, že planety mají ve středu

\footnotetext{
${ }^{46}$ Phenomena mají u Newtona odlišný epistemologický status než v běžném užití u jiných prŕírodních filosofů. $Z$ důvodů větší přehlednosti budu užívat tento termín vždy, když budu mluvit o tomto specifickém typu.

${ }^{47}$ Newton, Mathematical Principles, 797-801.

${ }^{48}$ Torretti, Philosophy of Physics, 71.
} 
oběžné dráhy Slunce. Tato data vycházejí z aplikací druhého a třetího Keplerova zákona ${ }^{49}$ na orbitální pohyb těles. ${ }^{50}$

Užití Keplerových zákonů je znamenitý př́klad odvození propozic $\mathrm{z}$ phenomen. $\mathrm{Z}$ pravidla ploch, které popisuje vztah mezi rychlostí tělesa a časem, Newton odvodil propozici charakterizující gravitační sílu jako pole zrychlení dostředivé síly směrem ke středu soustavy. Harmonické pravidlo, které určuje vzdálenost satelitu od centrálního tělesa a vztah mezi vzdáleností a siderickou periodou, ${ }^{51}$ umožňuje charakterizovat intenzitu tohoto zrychlení, která je nepřímo úměrná druhé mocnině vzdálenosti. ${ }^{52}$

Phenomena představují základ série propozic dokazujících platnost teorie obecné gravitace. Pro nás jsou nejdůležitější především Propozice 5, 6 a $7 . .^{53}$

Propozice 5: Tělesa obíhající Jupiter, Saturn a Slunce tíhnou směrem k jejich středu a vlivem gravitace jsou stahována $\mathrm{z}$ pohybu rovnoměrně přímočarého a udržována na zakřivených orbitách.

Zde Newton spojuje téměř všechna předchozí phenomena a přidává aplikaci prvního a druhého pohybového zákona. Díky pravidlu $2^{54}$ definuje gravitační sílu jako homogenní ve všech jednotlivých pozorování. Gravitační síla působí směrem ke všem planetám a je nepřímo úměrná druhé mocnině jejich vzdálenosti od středu gravitačního pole. Tyto př́pady Newton považuje za propozice odvozené z phenomen pomocí induktivní metody podpořené souhlasným měřením stejného parametru v různých dis-

\footnotetext{
${ }^{49}$ Druhý zákon, tzv. pravidlo ploch, nám říká, že velikost plochy, kterou opíše polohový vektor spojující střed oběžné dráhy a těleso obíhající kolem něj, je prrímo úměrná času. Čím více se těleso přibližuje $\mathrm{k}$ perihéliu, tím rychleji se pohybuje, a naopak čím více se vzdaluje směrem $\mathrm{k}$ aféliu, tím je jeho rychlost nižší. Třetí Keplerův zákon, tzv. hamornické pravidlo, nám dává do vztahu siderické periody a vzdálenosti středu soustavy a hmotného bodu, přičemž poměr je konstantní. Siderické periody obíhajících planet se rovnají vzdálenosti od středu oběžné dráhy umocněné na $3 / 2$.

${ }^{50}$ Pierre Duhem kritizoval Newtonovo vyvození principů obecné gravitace z Keplerových zákonů. Podle něj je gravitace v rozporu s druhým a třetím zákonem. Viz Pierre Duhem, The Aim and Structure of Physical Theory (Princeton: Princeton University Press, 1991), 193.

${ }^{51}$ Doba, která uplyne mezi dvěma konjunkcemi planety s touže stálicí, tedy čas potřebný k uskutečnění jednoho plného oběhového cyklu.

${ }^{52}$ Zákon převrácených čtverců (inverse-square law) popisuje vztah intenzity, např. gravitačního pole, a vzdálenosti, přičemž intenzita klesá s druhou mocninou vzdálenosti.

${ }_{53}$ Newton, Mathematical Principles, 805-15.

${ }^{54}$ Př́činy přiřazené př́rodním jevưm určitého typu musí být vždy stejné.
} 
krétních jevech, čímž získávají dle pravidla $4^{55}$ přinejmenším quam proxime pravdivost.

Propozice 6 dokládá platnost Newtonova argumentu přiřazujícího gravitaci charakter dostředivého pole zrychlení nepř́mo úměrného vzdálenosti. Odvolává se na různé prrípady poskytující souhlasné měření pro tělesa se stejným zrychlením a se stejnou vzdáleností od planety, kolem které obíhají. ${ }^{56}$

Propozice 6: Všechna tělesa tíhnou směrem ke každé z planet a v jakékoli dané vzdálenosti od středu planety je tíha tělesa směrem $k$ této planetě úměrná hmotnosti tělesa.

Dostředivá síla zde byla určena jako to, co bychom jazykem současné fyziky nazvali pole vytvářející zrychlení, přičemž poměr tíhy a hmotnosti je pro všechna tělesa stejný.

Propozice 7: Gravitační síla existuje univerzálně ve všech tělesech a je úměrná jejich hmotnosti.

Zde již dochází ke koncepčnímu posunu od gravitace jako dostředivé přitažlivé síly planet $\mathrm{k}$ pojetí gravitace jako univerzální síly párových interakcí mezi všemi tělesy, ${ }^{57}$ jejíž intenzita klesá s druhou mocninou vzdálenosti. Aplikací fundamentálních metodologických zásad metody demonstrativní indukce Newton vytvořil integrovaný systém vysvětlující veškerý pohyb v univerzu. ${ }^{58}$

${ }^{55} \mathrm{~V}$ experimentální filosofii by měly být propozice získané z přírodních jevů pomocí indukce považovány za zcela nebo alespoň přibližně pravdivé.

${ }^{56}$ Harper, Isaac Newton's Scientific Method, 265.

${ }^{57}$ Ibid., 290.

${ }^{58}$ Pro podrobnější rozpracování otázky, zda Newton přikládal gravitační síle povahu síly působící na dálku, viz Hylarie Kochiras, „Gravity and Newton's Substance Counting Problem,“" Studies in History and Philosophy of Science 40, no. 3 (2009): 267-80; John Henry, „Gravity and de Gravitatione: Development of Newton's Ideas on Action at a Distancem," Studies in History and Philosophy of Science 42, no. 1 (2011): 11-27; Eric Schliesser, „Newton's Substance Monism, Distant Action, and the Nature of Newton's Empiricism: Discussion of H. Kochiras ,Gravity and Newton's Substance Counting Problem, " Studies in History and Philosophy of Science 42, no. 1 (2011): 160-66; Steffen Ducheyne, „Newton on Action at a Distance and the Cause of Gravity, "Studies in History and Philosophy of Science 42, no. 1 (2011): 154-59; Hylarie Kochiras, „Gravity and Newton's Substance Counting Problem: Contextualizing the Problem," Studies in History and Philosophy of Science 42, no. 1 (2011): 167-84; John Henry, „Newton and Action at a Distance Between Bodies - a Response to Andrew Janiak's ,Three 


\section{Kritika hypoteticko-deduktivní metody}

Newtonova pozitivní teorie popisu gravitace má ještě jeden zásadní filosofický přesah, a tím je kritika mechanického materialismu. Ten zažíval v období 17. století značný rozmach a byl upřednostňován množstvím nejvýznamnějších přírodních filosofů té doby, jakým byli např. Robert Boyle, René Descartes ${ }^{59}$ či Christiaan Huygens. Bylo by však chybné si myslet, že např́íc jednotlivými proponenty byla sdílena jediná koherentní verze. Zatím co se všichni shodovali, že nutnou podmínkou povahy interakce těles je čistě mechanické vysvětlení, v otázce dostačujících podmínek již shoda nepanovala ${ }^{60}$

Primárně se Newton snaží vyvrátit karteziánskou formu mechanického materialismu, především jeho vysvětlení povahy gravitace. Jeho kritika ovšem nemá pouze teoretický rozměr. Jak jsme si mohli všimnout v rámci metody demonstrativní indukce, jediné validní explanace je možno získat odvozením propozic $\mathrm{z}$ phenomen, jež jsou následně induktivně zobecněny. Mechanický materialismu oproti tomu klade hypoteticko-deduktivní (HD) metodu. V Traite de la lumiere (1690) předkládá Huygens obecnou charakteristiku této metody:

V této oblasti můžeme vidět určitý typ demonstrací, která nemají natolik vysokou míru jistoty, jako ty užité v geometrii. Také metoda je odlišná. Zatímco geometrové dokazují své propozice na základě důkladně zavedených a nevyvratitelných principů, zde jsou principy testovány na základě inferencí, které je z nich možné odvodit. Povaha zkoumaného předmětu nedovoluje žádný jiný př́stup. Nicméně je možné tímto způsobem vytvořit závěry, jejichž platnost je jen malý kousek od úplné jistoty. K tomu dochází, když jsou důsledky výchozích principů v naprostém souhlasu s pozorovanými jevy a tím spíše, je-li těchto pozorování více. Nejjistější si však můžeme být $\mathrm{v}$ okamžiku, kdy na základě hypotézy predikujeme nové prŕrodní jevy, které následně pozorujeme. ${ }^{61}$

Concepts of Causation in Newton,“" Studies in History and Philosophy of Science 47 (2014): 91-97.

${ }^{59}$ Přestože Descartes nebyl materialistou v dnešním slova smyslu, když věřil v Boha a existenci duše (res cogitans) je podle mě správně jej řadit mezi mechanické materialisty v rámci způsobu explanace př́rody. Bůh u něj funguje jako prvotní příčina, nicméně vše v rámci res extenza funguje př́sně na mechanických základech. Postulát res cogitans na tom nic nemění, jelikož př́rodu můžeme zkoumat nezávysle a odděleně od zkoumání člověka a Descartes si v rámci popisu př́rody vystačí čistě v rámci mechanických intenzí.

${ }^{60}$ J. E. McGuire, „Boyle's Conception of Nature,“ Journal of History of Ideas 33, no. 4 (1972): 523.

${ }^{61}$ Michael R. Matthews, Scientific Background to Modern Philosophy (Indianapolis: Hackett Publishing Company, 1989), 126-27. 
V HD metodě jsou tedy hypotetické principy testovány experimentální verifikací pozorovatelných důsledků, které $\mathrm{z}$ nich můžeme vyvodit. ${ }^{62}$

Podle Belkinda hypotézy HD metody vždy překračují rámec toho, co jsme schopni zjistit $\mathrm{v}$ rámci několika experimentů a pozorování. Navíc mohou nastat př́pady, kdy jedna preferovaná hypotéza je v rozporu s jinou, která nicméně je také v souladu s pozorováním. Neexistuje tedy žádný spolehlivý postup, jak generovat hypotézy. Newton nás $\mathrm{v}$ pravidle $4^{63}$ varoval před vyvozováním propozic $\mathrm{z}$ phenomen. Pokud narazíme na phenomena, jež jsou v rozporu s vědeckou propozicí, měli bychom ji zavrhnout. Newton si tedy byl vědom falibility induktivní metody. Přestože připustil, že induktivní inference může být chybná na základě budoucích objevů, zdá se, že věřil v existenci induktivního pravidla, jež bezpečně vede cestu od daného souboru phenomen $\mathrm{k}$ vědeckým propozicím $\mathrm{z}$ nich odvozených. ${ }^{64}$

Brány jako hypotézy Kopernikánský heliocentrický systém i Braheho geoheliocentrický systém jsou stejně validní, protože oba jsou v souladu s pozorováním. HD metoda není schopna rozhodnout, který systém je reálným obrazem světa, protože predikce přírodních jevů je totožná. ${ }^{65}$ $\mathrm{Na}$ základě pečlivého měření a experimentu byl Newton schopen pomocí odvozování propozic z phenomen rozhodnout v otázce uspořádání sluneční soustavy ve prospěch heliocentrického systému. ${ }^{66}$ DI metoda se tedy ukazuje jako mnohem adekvátnější nástroj pro získávání inferencí než HD metoda.

$\mathrm{V}$ rámci zhodnocení validity a reliability vědeckých teorií je třeba klást důraz na jejich empirický úspěch. ${ }^{67}$ Newton nám tak v pravidle 4 dává významný analytický nástroj pro aplikaci při posuzování jednotlivých teorií, bez ohledu na to, jestli jsou založeny hypoteticky, nebo odvozeny $\mathrm{z}$ phenomen. Koncept empirického úspěchu teorie, tedy měření parametrů

\footnotetext{
${ }^{62}$ Harper, Isaac Newton's Scientific Method, 42.

${ }^{63} \mathrm{~V}$ experimentální filosofii by měly být propozice získané z phenomen pomocí indukce považovány za zcela nebo alespoň přibližně pravdivé bez ohledu na protikladné hypotézy, dokud jiná phenomena neučiní tyto propozice bud’ přesnější nebo podléhající výjimkám.

${ }^{64}$ Belkin, „Newton's Scientific Method,“ 140.

${ }^{65}$ Srv. René Descartes, Principles of Philosophy (Dordrecht: Kluwer, 1984), 90.

${ }^{66}$ Newton rozhodl v neprospěch obou hlavních teorií, protože identifikoval střed sluneční soustavy mírně mimo střed Slunce. Nicméně platí, že heliocentrický systém je v ohledu deskripce pohybu planet přinejmenším přibližně pravdivý, zatímco geoheliocentrický a samozřejmě i geocentrický systém jsou naprosto nepřesné.

${ }^{67}$ Teorie je empiricky úspěšná, pokud se jejím kauzálním parametrům dostane konvergentních a přesných výpočtů na základě phenomen, která se snaží vysvětlit. Viz William Harper, „Newton's Argument for Universal Gravitation," in The Cambridge Companion to Newton, eds. Robert Iliffe and George E. Smith (Cambridge: Cambridge University Press, 2016), 241.
} 
dle phenomen, která se daná teorie snaží vysvětlit, nám předkládá mnohem více prostředků pro odmítnutí nebo přijetí alternativních teorií, než hypoteticko-deduktivní model vědeckých inferencí. ${ }^{68}$

Teorie generované HD modelem jsou problematické také $\mathrm{z}$ hlediska epistemologické justifikace ontologického statusu teoretických entit. V případě, že teorie postuluje existenci nějakých entit nebo vnitřních či vnějších mechanismů, pak je otázka, do jaké míry je jejich existence přijatelná. Ontologický status hypotetických entit je determinován pouze na základě konfirmace jejich teoretických důsledků v rámci pozorování a experimentu. Přestože experiment a pozorování hrají důležitou roli i v rámci DI metody, naprosto klíčové je zde měření zakotvené v teorii. Větší empirický úspěch nám tedy poskytuje i vyšší míru justifikace pro existenci teoretických entit. Př́kladem mohou být rozlišná pojetí charakteru gravitační síly u Newtona a Descarta. ${ }^{69}$ Newton samozřejmě kritizoval Descartovu teorii vírů. ${ }^{70}$ Teorie, včetně její matematizace, o kterou se zasloužil Leibniz a Huygens, je neudržitelná $\mathrm{z}$ několika důvodů. Podle Newtona odporuje druhému Keplerovu zákonu a mechanická interakce částic víru by vedla k významným odchylkám, které ovšem nejsou pozorované. Dalším problematickým kosmickým jevem je pohyb komet, které zdánlivě narušují kruhový pohyb částic předávající planetám hybnost a často se pohybují v opačném směru.

Newton využívá vlastních metodologicko-teoretických východisek jako protiargument vůči mechanistické explanaci orbitálního pohybu založené čistě hypoteticky. Charakter gravitace jako párové interakce mezi tělesy, má

${ }^{68}$ Harper, Isaac Newton's Scientific Method, 362.

${ }^{69}$ Descartes v rámci HD modelu, vytvořil tzv. teorii vírů. Představme si vesmír jako obrovský vír částic hmoty, jejíž nejmenší částice se hromadí ve středu, protože mají nejmenší odstředivou sílu. Vzájemná interakce a shlukování částic mezi nimi vytváří tření, což způsobuje vyzařování tepla a světla u Slunce a ostatních hvězd. Větší částice se spojují a vytvářejí planety, které jsou unášeny vírem po fixních orbitách v závislosti na jejich hustotě. Pokud se planeta přiblíží ke středu, narazí na menší a rychleji se pohybující částice, a ty předají část svého pohybu planetě, jež získá vyšší odstředivou sílu a dostane se tak dále od středu. Ve větší vzdálenosti pak pochopitelně narazí na větší a pomaleji se pohybující částice, čímž dojde ke zpomalení jejího vlastního pohybu a opětovnému přiblížení se ke středu víru. Veškeré interakce tedy můžeme vysvětlit na základě mechanického pohybu částic. Viz Henry, Scientific Revolution, 72.

${ }^{70}$ Descartova kosmologická teorie byla pouze kvalitativní deskripcí charakteru mechanických interakcí mezi tělesy, nicméně představovala v tomto směru nejvlivnější alternativu k teorii obecné gravitace. Huygens a Leibniz se zasadili o její matematizaci, nicméně stále vzrůstající obliba Newtonovy varianty a její větší empirický úspěch zapř́ičinil, že teorie vírů byla později opuštěna. Srv. Stephen Gaukroger, Descartes' System of Natural Philosophy (Cambridge: Cambridge University Press, 2002), 159-60. 
vyšší míru justifikace než postulát existence vírů částic. To je zdůvodněno vyšší empirickou adekvátností teorie založené na měření. Obecně se tak minimalizuje riziko nekontrolovatelného množení obskurních entit v př́rodní filosofii, jež s sebou HD metoda nutně přináší.

\section{Hypotheses non fingo}

Newtonův antipatický vztah vůči roli hypotézy ve vědecké praxi je nepochybný. Deduktivní induktivismus generuje v tomto směru adekvátnější a empiricky úspěšnější teorie než jiné varianty. Propozice jsou zde odvozeny ze souboru precizovaných a validních dat a následně induktivně zobecněny. Za pomoci omezeného množství principů dokázal Newton vysvětlit charakter působení gravitační síly jako univerzální párové interakce, přičemž intenzita gravitačního pole klesá s druhou mocninou vzdálenosti. Explanační síla takové teorie je založena na validitě výchozích předpokladů a je vyšší než v prŕípadě hypoteticko-deduktivně založených teorií.

Slavné hypotheses non fingo tedy nemá pouze charakter metodologické maximy, ale také teoretického předpokladu. Pouhá konfirmace teorie založená předně na validitě jejích pozorovatelných důsledků nestačí. Při deskripci teoretických entit musíme aplikovat metodu experimentu a měření zakotveném $\mathrm{v}$ teorii. Jinými slovy, naše výsledná teorie nesmí být určena hypotetickými předpoklady, ale musí vycházet $\mathrm{z}$ výsledků experimentální metody.

\section{Bibliografie:}

Belkind, Ori. „Newton's Scientific Method and the Law of Gravitation.“ In Interpreting Newton: Critical Essays, edited by Andrew Janiak and Eric Schliesser, 138-68. Cambridge: Cambridge University Press, 2012. https://doi.org/10.1017/CBO9780511994845.009.

Cohen, I. Bernard. „Newton's Concept of Force and Mass, With Notes on the Laws of Motion." In The Cambridge Companion to Newton, edited by Robert Iliffe and George E. Smith, 57-84. Cambridge: Cambridge University Press, 2016. https://doi.org/10.1017/CCOL0521651778.003.

Copernicus, Nicolaus. „Commentariolus.“ In Three Copernican Treatises, edited by Edward Rosen, 55-90. New York: Octagon Books, 1971. 
Cushing, James T. Philosophical Concepts in Physics: The Historical Relation Between Philosophy and Scientific Theories. Cambridge: Cambridge University Press, 1998. https://doi.org/10.1017/CBO9781139171106.

De Gandt, François. Force and Geometry in Newton's Principia. Princeton: Princeton University Press, 2014.

Descartes, René. Principles of Philosophy. Translated by Valentine Rodger Miller and Reese P. Miller. Dordrecht: Kluwer, 1984.

Dorling, John. „Demonstrative Induction: Its Significant Role in the History of Physics." Philosophy of Science 40, no. 3 (1973): 360-72. https://doi.org/10.1086/288537.

Ducheyne, Steffen. „Newton on Action at a Distance and the Cause of Gravity.“ Studies in History and Philosophy of Science 42, no. 1 (2011): 154-59. https://doi.org/10.1016/j.shpsa.2010.11.003.

Duhem, Pierre. The Aim and Structure of Physical Theory. Translated by Philip P. Wiener. Princeton: Princeton University Press, 1991.

Gaukroger, Stephen. Descartes' System of Natural Philosophy. Cambridge: Cambridge University Press, 2002. https://doi.org/10.1017/CBO9780511606229.

Guicciardini, Niccoló. Reading the Principia: The Debate on Newton's Mathematical Methods for Natural Philosophy From 1687 to 1736. Cambridge: Cambridge University Press, 1999. https://doi.org/10.1017/CBO9780511524752.

Hanson, Norwood R. „Hypotheses Fingo.“ In The Methodological Heritage of Newton, edited by Robert E. Butts and John W. Davis, 14-33. Oxford: Blackwell, 1970. https://doi.org/10.3138/9781442632783-003.

Harper, William L. Isaac Newton's Scientific Method: Turning Data Into Evidence About Gravity and Cosmology. Oxford: Oxford University Press, 2011. https://doi.org/10.1093/acprof:oso/9780199570409.001.0001.

Harper, William. „Newton's Argument for Universal Gravitation.“ In The Cambridge Companion to Newton, edited by Robert Iliffe and George E. Smith, 229-60. Cambridge: Cambridge University Press, 2016. https://doi.org/10.1017/CCO9781139058568.007.

Henry, John. The Scientific Revolution and the Origins of Modern Science. New York: Palgrave, 2002. 
Henry, John. „Gravity and de Gravitatione: Development of Newton's Ideas on Action at a Distance." Studies in History and Philosophy of Science 42, no. 1 (2011): 11-27. https://doi.org/10.1016/j.shpsa.2010.11.025.

Henry, John. „Newton and Action at a Distance Between Bodies - a Response to Andrew Janiak's ,Three Concepts of Causation in Newton." Studies in History and Philosophy of Science 47 (2014): 91-97. https://doi.org/10.1016/j.shpsa.2014.03.001.

Janiak, Andrew. Newton as Philosopher. Cambridge: Cambridge University Press, 2008. https://doi.org/10.1017/CBO9780511481512.

Kochiras, Hylarie. „Gravity and Newton's Substance Counting Problem.“ Studies in History and Philosophy of Science 40, no. 3 (2009): 267-80. https://doi.org/10.1016/j.shpsa.2009.07.003.

Kochiras, Hylarie. „Gravity and Newton's Substance Counting Problem: Contextualizing the Problem." Studies in History and Philosophy of Science 42, no. 1 (2011): 167-84. https://doi.org/10.1016/j.shpsa.2010.11.005.

Lerner, K. Lee, and Brenda Wilmoth Lerner. Scientific Thought: In Context. Gale: Cengage Learning, 2009.

Matthews, Michael R. Scientific Background to Modern Philosophy. Indianapolis: Hackett Publishing Company, 1989.

McGuire, J. E. „Boyle's Conception of Nature.“ Journal of History of Ideas 33, no. 4 (1972): 523-42. https://doi.org/10.2307/2708855.

Newton Isaac. Mathematical Principles of Natural Philosophy. Translated by I. Bernard Cohen and Anne Whitman. Berkeley: University of California Press, 1999.

Newton, Isaac. „Isaac Newton to Robert Hooke, February 5, 1675/6.“ In The Correspondence of Isaac Newton, Vol. 1 1661-1675, edited by Herbert W. Turnbull, 416-25. Cambridge: Cambridge University Press, 1959.

Newton, Isaac. „Isaac Newton to Roger Cotes, March 31, 1713.“ In The Correspondence of Isaac Newton, Vol. 5, 1709-1713, edited by A. Rupert Hall and Laura Tilling. Cambridge: Cambridge University Press, 1975.

Newton, Isaac. Philosophical Writings. Edited by Andrew Janiak. Cambridge: Cambridge University Press, 2004.

Newton, Isaac. Unpublished Scientific Papers of Isaac Newton. Edited by A. Rupert Hall and Marie Boas Hall. Cambridge: Cambridge University Press, 1962. 
Norton, John D. „Eliminative Induction as a Method of Discovery: How Einstein Discovered General Relativity." In The Creation of Ideas in Physics, edited by Jarrett Leplin, 29-69. Dordrecht: Kluwer, 1995. https://doi.org/10.1007/978-94-011-0037-3_3.

Schliesser, Eric. „Newton's Substance Monism, Distant Action, and the Nature of Newton's Empiricism: Discussion of H. Kochiras ,Gravity and Newton's Substance Counting Problem." 'Studies in History and Philosophy of Science 42, no. 1 (2011): 160-66. https://doi.org/10.1016/j.shpsa.2010.11.004.

Smith, George E. „The Methodology of the Principia.“ In The Cambridge Companion to Newton, edited by Robert Iliffe and George E. Smith, 187-228. Cambridge: Cambridge University Press, 2016. https://doi.org/10.1017/CCO9781139058568.006.

Torretti, Roberto. The Philosophy of Physics. Cambridge: Cambridge University Press, 1999. 